\title{
Analysis of Antenatal Care Visit at the Work Area of Kilasah Health Centre Serang City in 2019
}

\author{
Shinta Novelia ${ }^{*}$, Rukmaini Rukmaini², Mulliawati Tohir ${ }^{3}$ \\ 1,2,3Midwifery Department, Universitas Nasional Jakarta, shinta.novelia@civitas.unas.ac.id (Corresponding Author)
}

\begin{abstract}
Article Info:
Submitted:

16-08-2021

Revised:

30-08-2021

Accepted:

01-11-2021

DOI:

https://doi.org/10.53713/nhs.v1i3.52

ABSTRACT

The government is obliged to guarantee equal access to antenatal care (ANC) between urban and rural areas. Indonesia Ministry of Health declares at least 6 time of ANC visit through pregnancy. The high rate of maternal and infant mortality is partly due to the frequency of irregular pregnancy check-ups. This is a problem because not all pregnant women check their pregnancy regularly so that abnormalities that arise in pregnancy cannot be detected as early as possible. This study aimed to analyze factors related to antenatal care (ANC) visits in the Kilasah Health Center Work Area Serang City in 2019. The research is a cross-sectional study. The research sample was 91 midwives at the Work Area of the Kilasah Health Center, Serang City. From the results of the study, it was known that factors related to ANC visits in the Kilasah Health Center Work Area were knowledge $(p=0.023)$, education $(p=0.000)$, and family support $(p=0.004)$. It is hoped that the the Health Centre more intensive in providing health education, so that public health knowledge will increase and there will be changes in public health behavior towards the better. Midwife need to motivate pregnant women to practice antenatal care at least 6 times as suggested by Ministry of Health as the standard.
\end{abstract}

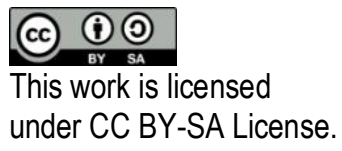

Keywords: antenatal care visit; education; family supports; knowledge; pregnant women

\section{INTRODUCTION}

The high Maternal Mortality Rate (MMR) in several world regions showed inequality in access to quality health services. Indonesia is among the countries with the third-highest MMR in Southeast Asian countries after Myanmar and Laos (Achadi, 2019). The MMR in Indonesia in 2017 was 177 deaths per 100,000 live births. The MMR in Indonesia has gradually decreased from 207 per 100,000 live births in 2013 to 177 per 100,000 live births in 2017 (Wulandari \& Laksono 2020). The high MMR also applies to the Philippines. The maternal mortality ratio in the Philippines stood at 121 deaths per 100,000 live births in 2017 to 124 deaths per 100,000 live births in the previous year. Data in Indonesia and the Philippines show a gradual downward trend but have not yet reached the SDGs target of less than 70 per 100,000 live births (WHO, 2020). In Banten Province, based on data from the Banten Provincial Health Office in 2018, MMR reached 264 cases caused by bleeding was 75 cases (28.4\%), hypertension in pregnancy was 63 cases (31.2\%), infection was 25 cases $(9.4 \%)$, circulatory system disorders was 28 cases (10.6\%) from other causes was 67 cases (25.4\%) (Banten Provincial Health Office, 2018).

In an effort to reduce MMR in Indonesia, the Indonesian Ministry of Health emphasizes on providing quality maternal health services in the community. One of these efforts is to provide antenatal care (ANC) services. Antenatal care has a real positive impact on reducing maternal and infant mortality rates. With the presence of antenatal care, pregnant women can know the growth of the fetus and its health, pregnant women can also express the complaints experienced so that health workers can provide information and appropriate actions.

The regularity of ANC can be demonstrated through the frequency of visits, but the problem is that not all pregnant women check their pregnancy regularly so that abnormalities that arise in pregnancy cannot be detected as early as possible. The impact of non-compliance in pregnancy tests, among others, is that pregnant women will receive less information about the correct way of pregnancy care, not detecting danger signs of pregnancy early, not detecting anemia of pregnancy that can cause bleeding during delivery, not detecting signs of labor complications early on and not detecting comorbidities and complications during pregnancy. Non-compliance in pregnancy examinations also triggers the high maternal mortality rate (MMR) (De Wet, 2016). 
The latest development of data from Basic Health Research in 2018 reported that the national coverage of pregnant women who checked their pregnancy with health workers in the 1st trimester (K1) was $96.1 \%$. The coverage of pregnancy examination (K4) was $74.1 \%$. From this data, there was a difference of $22 \%$ of mothers who received the ideal K1 who did not continue ANC according to the minimum standard (K4) (Riskesdas, 2018). The level of maternal compliance in checking her pregnancy is influenced by several factors. The results of data observations at the Kilasah Health Center showed that the coverage of antenatal care visits for pregnant women in 2018 was $85 \% \mathrm{~K} 1$ and $75.5 \%$ K4. Meanwhile, in the January-April 2019 period, from a target number of 916 pregnant women, K1 coverage was $30.2 \%$ or 277 pregnant women and K4 coverage was $26 \%$ or 238 pregnant women. When viewed from the coverage of $\mathrm{K} 1$ and K4 antenatal care visits at the Kilasah Health Center, it is still below the national target standard of $100 \%$ (Kilasah Health Center, 2019).

The results of the preliminary study by interviewing 10 pregnant women found the fact that 7 pregnant women (70\%) had poor knowledge about antenatal care or antenatal care, this can be seen from the lack of pregnant women understanding the benefits of antenatal care. They go to the health service only to see the gender of the fetus they are carrying through ultrasound, not with the main purpose of knowing the state of the pregnancy. From the interview results, the author also found that there was still a lack of family support for pregnant women, this was known from the majority of pregnant women who said that their husbands rarely asked about their pregnancy, and almost all of them said that their husbands did not prepare special costs for their delivery preparation. Based on the description of the background above and considering the importance of antenatal care for pregnant women, thus there is a need to study antenatal care visits analysis (anc) at the work area of Kilasah Health Center Serang City in 2019". The objective is to analyze factors related to ANC visit at the work area of Kilasah Health Center Serang City in 2019.

\section{METHOD}

The research design is cross sectional study. The population in this study was all pregnant women at the work area of the Kilasah Public Health Center, Serang City in July 2019 including 916 pregnant women. Based on the calculation of the Slovin formula it was obtained a total sample of 91 respondents. Sampling method was accidental sampling. The researhc has been conducted in Juli 2019. The variables were ANC visit, knowledge, age, education, parity, family support. A questionnaie has been developed by the researcher to analyze knoeledge and family support. It has been tested for validity and reliablity (cronbach $a=0.89$ ).

\section{RESULT}

\section{Univariate Analysis}

Table 1 shows that majority of the respondents had incomplete antenatal care (75.8\%), 37 mothers aged 20-35 years old (40.7\%), 41 pregnant women with junior high school education (45.1\%), 49 pregnant women had primiparous parity, 60 pregnant women have low economic status $(65.9 \%)$ and 50 pregnant women lack of family support (58.8\%).

Table 2 shows that out of 69 respondents who had poor knowledge, majority of them $(75.4 \%)$ had incomplete ANC visits. There was a significant relationship between knowledge and antenatal care (ANC) visits to pregnant women in the Kilasah Health Center Work Area in $2019(\mathrm{p}=0.023)$. Out of 41 respondents who had junior high school education background, majority of them (85.4\%) had incomplete ANC visit. there was a significant relationship between education and antenatal care (ANC) visits among pregnant women in the Kilasah Health Center Work Area in $2019(p=0.005)$. out of 50 respondents who lack of family support, majority of them (82\%) had incomplete ANC visits. There was a relationship between between family support and ANC visits among pregnant women at the Kilasah Health Center Work Area in $2019(\mathrm{p}=0.005)$. 
Table 1. The univariate analysis of all variable

\begin{tabular}{|c|c|c|}
\hline Variabel & $\mathrm{n}$ & $\%$ \\
\hline \multicolumn{3}{|l|}{ ANC visit } \\
\hline Not Complete & 62 & 68.1 \\
\hline Complete & 29 & 31.9 \\
\hline \multicolumn{3}{|l|}{ Knowledge } \\
\hline Poor & 69 & 75.8 \\
\hline Enough & 13 & 14.3 \\
\hline Good & 9 & 9.9 \\
\hline \multicolumn{3}{|l|}{ Age } \\
\hline$<20$ years & 32 & 35.2 \\
\hline $20-35$ years & 37 & 40.7 \\
\hline 35 years & 22 & 24.2 \\
\hline \multicolumn{3}{|l|}{ Education levels } \\
\hline Elementary school & 22 & 24.2 \\
\hline Junior High School & 41 & 45.1 \\
\hline Senior High School & 19 & 20.9 \\
\hline University & 9 & 9.9 \\
\hline \multicolumn{3}{|l|}{ Parity } \\
\hline Primipara & 49 & 53.8 \\
\hline Multipara & 42 & 46.2 \\
\hline \multicolumn{3}{|l|}{ Economic status } \\
\hline Under & 60 & 65.9 \\
\hline High & 31 & 34.1 \\
\hline \multicolumn{3}{|l|}{ Family support } \\
\hline Not supported & 50 & 54.9 \\
\hline Supported & 41 & 45.1 \\
\hline Total & 91 & 100 \\
\hline
\end{tabular}

Table 2. The relationship between knowledge, education, and family support toward ANC visit

\begin{tabular}{|c|c|c|c|c|c|c|c|}
\hline & \multicolumn{4}{|c|}{ ANC visit } & \multicolumn{2}{|c|}{ Total } & \multirow{3}{*}{$p$} \\
\hline & \multicolumn{2}{|c|}{ Incomplete } & \multicolumn{2}{|c|}{ Complete } & \multirow[b]{2}{*}{$\mathrm{n}$} & \multirow[b]{2}{*}{$\%$} & \\
\hline & $\mathrm{n}$ & $\%$ & $\mathrm{n}$ & $\%$ & & & \\
\hline \multicolumn{8}{|l|}{ Knowledge } \\
\hline Poor & 52 & 75.4 & 17 & 24.6 & 69 & 100 & 0.023 \\
\hline Enough & 5 & 38.5 & 8 & 61.5 & 13 & 100 & \\
\hline Good & 5 & 55.6 & 4 & 44.4 & 9 & 100 & \\
\hline \multicolumn{8}{|l|}{ Education level } \\
\hline Elementary school & 19 & 86.4 & 3 & 24.6 & 22 & 100 & 0.000 \\
\hline Junior high school & 35 & 85.4 & 6 & 14.6 & 41 & 100 & \\
\hline Senior high school & 8 & 42.1 & 11 & 61.5 & 9 & 100 & \\
\hline College/ university & 0 & 0 & 9 & 100 & 9 & 100 & \\
\hline \multicolumn{8}{|l|}{ Family support } \\
\hline Lack & 41 & 82,0 & 9 & 18,0 & 50 & 100 & 0.004 \\
\hline Good & 21 & 51,2 & 20 & 48,8 & 41 & 100 & \\
\hline Total & 27 & 26.5 & 75 & 73.5 & 102 & 100 & \\
\hline
\end{tabular}

\section{DISCUSSION}

Table 1 shows that majority of the respondents had incomplete antenatal care $(75.8 \%), 37$ mothers aged $20-35$ years old $(40.7 \%), 41$ pregnant women with junior high school education $(45.1 \%), 49$ pregnant women had primiparous parity, 60 pregnant women have low economic status $(65.9 \%)$ and 50 pregnant women lack of family support $(58,8 \%)$.

Antenatal care (ANC) visits or antenatal care are visits by a pregnant woman to a midwife or doctor as early as possible since she feels she is pregnant to receive antenatal care/care. At each prenatal care, the officer collects and 
analyzes data regarding the mother's condition through history taking and physical examination to obtain a diagnosis of intrauterine pregnancy and the presence or absence of problems or complications (Saifudin, 2010). According to Chimatiro (2018), the importance of conducting ANC visits or examinations early in pregnancy is for screening, and treatment of anemia, planning for delivery, and recognizing complications due to pregnancy and their treatment. The ANC visit is the contact of pregnant women with care providers to assess the health and well-being of the baby as well as the opportunity to obtain information about matters related to their pregnancy. By doing ANC can prevent things that are not good for the mother and fetus.

From the results of the study, it can be concluded that the coverage of antenatal care visits in the Kilasah Health Center Work Area is still below the set target of $100 \%$, this is actually very unfortunate considering the benefits of conducting examination visits. As previously explained, the purpose of prenatal care is to ensure that pregnant women can go through their pregnancy, delivery and postpartum well and safely, and produce healthy babies.

Table 2 shows that out of 69 respondents who had poor knowledge, majority of them (75.4\%) had incomplete ANC visits. There was a significant relationship between knowledge and antenatal care (ANC) visits to pregnant women in the Kilasah Health Center Work Area in $2019(p=.023)$. The results of this study indicate that pregnant women who have high knowledge are more complete in conducting ANC visits compared to pregnant women who have low knowledge. This is in accordance with Notoatmodjo's (2012) theory which says that knowledge or cognitive is a very important domain for the formation of one's actions. The higher the level of knowledge of pregnant women who are broad and supportive, the more positive things they will consider, they will tend to know when it is time for her to make antenatal care visits with the time that has been set. On the other hand, a previous research conducted by Adila et al (2021) found that workers' support statistically became the most influencing factor for the hhusbands to support their wives in ANC visits, the health workers need to provide a couple-based education about ANC and pregnancy, facilitating an education class for pregnant women's husbands and providing more information about ANC.

Table 2 shows that out of 41 respondents who had junior high school education background, majority of them $(85.4 \%)$ had incomplete ANC visit. there was a significant relationship between education and antenatal care (ANC) visits among pregnant women in the Kilasah Health Center Work Area in $2019(p=.005)$. Nursalam (2008) said that the higher a person's education level, the easier it is to receive information so that the more knowledge they have. Adequate education will make it easier for a mother to receive information about pregnancy from various sources and it will be easier for her to realize and receive this information so that her knowledge will increase. On the other hand, a lack of education will hinder the development of a person's attitude towards the newly introduced values.

The results is related to previous study which found that women who had higher education level were more likely to attend at least four ANC visits compared to those with no this was especially true in the urban areas (Muyunda Makasa, Jacobs, Musond \& Michelo, 2016). These results indicate that a person's level of education is closely related to compliance in conducting antenatal care visits. With the high education of a person, the more knowledge gained, especially knowledge about pregnancy, so that by knowing this knowledge, the motivation to make antenatal care visits increases. Pregnant women are suggested to improve education in order to aware of ante natal care.

Table 2 shows that out of 50 respondents who lack of family support, majority of them (82\%) had incomplete ANC visits. There was a relationship between between family support and ANC visits among pregnant women at the Kilasah Health Center Work Area in $2019(p=.005)$. A previous study found that Improving women's knowledge of pregnancyrelated risks and involving family members, particularly the husband and importantly for less-educated women, improved adherence to IFA supplementation (Wiradnyani, Khusun, Achadi, Ocviyanti, \& Shankar, 2016). ANC visit opportunities must be optimized to provide women with sufficient numbers of IFA tablets along with health information (especially on pregnancy-related risks) and partner support counselling. Furthermore, a study conducted in India found the impact of family support on ANC visit (Kumar et al., 2019). A half of the women did not receive the minimum recommended ANC visits, however the utilisation of TT immunisation was almost universal. The positive association of full ANC with ICDS utilisation and child's father involvement may be leveraged for increasing the uptake of full ANC. Strategies to address the socio-demographic factors associated with low and inequitable utilisation of full ANC are imperative for strengthening India's maternal health program. In addition there was a correlation between family support and ANC visits feequency (Sampoera, Wardani, \& Hapsari, 2020). 


\section{CONCLUSION}

Based on the results of the study, it can be concluded that the factors related to ANC Visits are knowledge, education and family support. Based on the findings in this study, the researchers suggest that the health centre as the spearhead of the government in building public health in the promotive and preventive fields need to improve their programs especially antenatal care. It is hoped that the health centre will be more active to share to community the health education and counseling, so that public health knowledge becomes better and there is a change in public health behavior towards the better. Midwife need to motivate pregnant women and their family to visit health facility to join antenatal care at least 6 times through pregnancy. Future research is needed to explore other variables related to ANC visits.

\section{REFERENCES}

Achadi, E. L. (2019). Maternal and Neonatal Death in Indonesia (Kematian Maternal dan Neotatal di Indonesia) [Internet]. Jakarta.

Adila, H. L., Suyatno, S., \& Dharmawan, Y. (2021). Health workers' support as the most influencing factor for husbands' support in antenatal care visits. Annals of Tropical Medicine and Public Health, 24, 24-181.

Banten Provincial Health Office. (2018). Data Angka Kematian Ibu di Provinsi Banten. Serang.

Chimatiro, C. S., Hajison, P., Chipeta, E., \& Muula, A. S. (2018). Understanding barriers preventing pregnant women from starting antenatal clinic in the first trimester of pregnancy in Ntcheu District-Malawi. Reproductive health, 15(1), 1-7.

De Wet, N. (2016). Pregnancy and death: An examination of pregnancy related deaths among adolescents in South Africa. South African Journal of Child Health, 10(3), 151-155.

Dinkes Kabupaten Serang, (2018). DataAngka Kematian Ibu diKabupatenSerang. Serang.

Kumar, G., Choudhary, T. S., Srivastava, A., Upadhyay, R. P., Taneja, S., Bahl, R., ... \& Mazumder, S. (2019). Utilisation, equity and determinants of full antenatal care in India: analysis from the National Family Health Survey 4. BMC pregnancy and childbirth, 19(1), 1-9.

Muyunda, B., Makasa, M., Jacobs, C., Musonda, P., \& Michelo, C. (2016). Higher educational attainment associated with optimal antenatal care visits among childbearing women in Zambia. Frontiers in public health, 4, 127.

Notoatmodjo. S. (2012). Promosi Kesehatan dan IImu Perilaku. Jakarta : Rineka Cipta

Nursalam, (2008), Konsep danPenerapan Metodologi Penelitian IImu Keperawatan, Jakarta

Riskesdas (2018). Riset Kesehatan Dasar. Jakarta : Kementerian Kesehatan RI

Sampoera, W. K., Wardani, H. E., \& Hapsari, A. (2020, December). The Correlation Between Level of Knowledge, Socio-Economic Status, Health Care Support, and Family Support With the Frequency of Pregnancy Examination Visits in Nganjuk. In The 1st International Scientific Meeting on Public Health and Sports (ISMOPHS 2019) (pp. 72-76). Atlantis Press.

SDKI. (2012). Survei Demografi Kesehatan Indonesia. Jakarta :Kementerian Kesehatan RI.

Wulandari, R. D., \& Laksono, A. D. (2020). Determinants of knowledge of pregnancy danger signs in Indonesia. PLoS One, 15(5), e0232550.

WHO. (2020). Maternal mortality ratio (modeled estimate, per 100,000 live births). https://data.worldbank.org/indicator/SH.STA.MMRT.

Wiradnyani, L. A. A., Khusun, H., Achadi, E. L., Ocviyanti, D., \& Shankar, A. H. (2016). Role of family support and women's knowledge on pregnancy-related risks in adherence to maternal iron-folic acid supplementation in Indonesia. Public health nutrition, 19(15), 2818-2828. 